\title{
Effect of different biofuels on common rail injector flow rate
}

In this study dynamic flow rates of a common rail injector using diesel fuel and different biofuels were determined. As biofuels, fatty acid methyl esters originating from canola, poultry, cattle and used cooking oil were tested. The tested fuels exhibited different physical properties e.g. density and viscosity. Measurements of the injector delivery rates were performed on a test stand designed for determination of injectors and injection pumps characteristics. Each fuel was tested at temperatures between 30 and $60^{\circ} \mathrm{C}$, under injection pressure in the range of 30-180 MPa and injection time in the range of 200-1600 microseconds. The results showed differences in injector flow rates depending on used fuel, however different fuel properties affected amount of fuel injected especially at short injection durations.

Key words: oils \& lubrication, engines, injector, diesel, biodiesel

\section{Introduction}

Nowadays, there is a strong emphasis on reducing the negative impact of internal combustion engines on the environment and increasing the energy efficiency contained in the fuel. In diesel engines, the combustion efficiency and emission of toxic exhaust gas components are significantly influenced by the fuel injection process into the combustion chamber. The main parameters determining the fuel spray quality are the injection pressure and the amount, shape and size of the injector holes. Conducted research on the possibilities to increase injection pressure to 250 and even 300 $\mathrm{MPa}$ [1, 5, 20] and research towards reducing injector holes, primarily in the context of reducing $\mathrm{NO}_{\mathrm{x}}$ and particulate emissions $[26,27]$. However, increasing the pressure in the fuel system and reducing the size of the injector holes determines the rise of fuel flow velocity, which affects the appearance of turbulent flow and the occurrence of cavitation. This results in increased wear of the fuel system components during operation $[5,16]$. Besides, the appearance of cavitation results in improvement of turbulence at the output of the injector, but may reduce the fuel flow [8, 18]. For this reason, the total amount of fuel injected into the combustion chamber and the level of fuel flow are the main factors characterizing the fuel injection process. Mainly dependent on fuel injection pressure, and the injector opening time. Determining the actual fuel flow rate allows to characterize the injector operation and comparison, especially in cases where the fuel is modified $[11,13]$.

Many factors affect the use of fuels other than diesel fuel in Diesel engine. For many years, the main reason given by the authors of scientific works are limited resources of fossil fuels. As an alternative to diesel, it is possible to use vegetable oils and their derivatives [22, 24]. On the one hand, pure vegetable oils are characterized by availability, low content of aromatic hydrocarbons and sulfur, and on the other hand have high viscosity and higher density, especially at low temperatures. As derivatives of oils, methyl esters of higher fatty acids, which are obtained by the transesterification of vegetable oils, are used [9]. The use of esters is currently the best way to use natural resources as a fuel to replace diesel. However, the production this type of fuel results in the use of edible oils for energy purposes and limiting their availability to comestible purpose. Therefore research is being undertaken in which the sources of biofuels are raw materials [21], plant [6] and animal [7]. This allows for diversification of raw materials for energy purposes, but also differentiates the chemical composition derived biofuels, which complicates their possible use in diesel engines [23].

Application of biofuels, especially second generation biofuels, necessitates the modification of the fuel systems due to different chemical composition and changed physicochemical properties [2, 3, 10]. Composition and properties are determined by the origin of raw materials or waste materials from which biofuels are produced [14]. A method of biofuel production, i.e. the type of catalyst used, or the presence of various contaminants from processing raw materials is also important [12]. Adaptation of diesel engines to chemical composition, density, viscosity, fractional composition, surface tension of diesel, makes the use of biofuel as an additive (e.g. B10, B20, B50) or as single fuel (B100) significantly changes fuel flow parameters, and consequently the process of combustion [19]. In many works, the authors point to the positive effect of the use biofuels on $\mathrm{CO}, \mathrm{HC}, \mathrm{PM}$ and $\mathrm{CO}_{2}$ emissions value, however, the high oxygen content in biofuels can lead to increased $\mathrm{NO}_{\mathrm{x}}$ emissions [25]. In addition, the use of biofuels, due to lower calorific value, results in lower engine performance and increased fuel consumption [4, 17]. However, today's common-rail systems can improve engine performance, reduce fuel consumption, and emissions of toxic compounds. It is important to properly select parameters such as injection pressure, injector opening time, so knowing the injection characteristics and fuel flow allows you to optimize these [17]. The purpose of the study was to investigate the fuel flow characteristics of injectors for biofuels produced from vegetable oils and waste fats (vegetable and animal origin).

\section{Experimental conditions}

The examinations were carried out using a six fuels. Table 1 shows the main parameters and table 2 shows main property of the tested fuels. All fuels were tested in temperature $30,40,50$ and $60^{\circ} \mathrm{C}$, under injection pressures, from range 30 to $180 \mathrm{MPa}$. The injection time for each tested pressure was changed between 200 and 1600 microseconds. 
Table 1. Main parameters of the tested fuels

\begin{tabular}{|l|c|c|c|c|c|c|}
\hline $\begin{array}{l}\text { Common } \\
\text { name of faty } \\
\text { acide methyl } \\
\text { ester }\end{array}$ & $\begin{array}{c}\text { Carbon no.: } \\
\text { double bond } \\
\text { no. }\end{array}$ & BIO 1 & BIO2 & BIO3 & BIO4 & BIO5 \\
\hline Myristic & $\mathrm{C} 14: 0$ & - & - & - & 2.65 & 0.23 \\
\hline Palmitic & $\mathrm{C} 16: 0$ & 0.55 & 0.45 & 20.8 & 26.12 & 8.56 \\
\hline Palmitoleic & $\mathrm{C} 16: 1$ & 4.6 & 4.57 & - & 3.21 & 0.42 \\
\hline Stearic & $\mathrm{C} 18: 0$ & 1.63 & 1.65 & 6.3 & 21.33 & 2.11 \\
\hline Oleic & $\mathrm{C} 18: 1$ & 61.96 & 61.82 & 44.6 & 37.4 & 61.72 \\
\hline Linoleic & $\mathrm{C} 18: 2$ & 18.11 & 18.19 & 15.7 & 4.52 & 18.18 \\
\hline Linolenic & $\mathrm{C} 18: 3$ & 9.6 & 9.75 & 0.85 & 0.58 & 6 \\
\hline Arachidic & $\mathrm{C} 20: 0$ & 0.57 & 0.58 & - & & \\
\hline Eicosenoic & $\mathrm{C} 20: 1$ & 1.43 & 1.47 & - & & \\
\hline Others & & 1.55 & 1.52 & 11.75 & 4.19 & 2.78 \\
\hline
\end{tabular}

Table 2. Main property of the tested fuels

\begin{tabular}{|l|l|l|l|l|l|l|}
\hline Fuel property & BIO 1 & BIO2 & BIO3 & BIO4 & BIO5 & Diesel \\
\hline Density @ 15 ${ }^{\circ} \mathrm{C}\left(\mathrm{kg} / \mathrm{m}^{3}\right)$ & 882.0 & 879.0 & 872.9 & 878.0 & 884.9 & 843.2 \\
\hline Density @ 30 ${ }^{\circ} \mathrm{C}\left(\mathrm{kg} / \mathrm{m}^{3}\right)$ & 871.9 & 868.9 & 862.8 & 867.9 & 875.0 & 832.3 \\
\hline Density @ 40 ${ }^{\circ} \mathrm{C}\left(\mathrm{kg} / \mathrm{m}^{3}\right)$ & 865.2 & 862.2 & 856.0 & 861.2 & 868.4 & 825.1 \\
\hline Density @ 50 ${ }^{\circ} \mathrm{C}\left(\mathrm{kg} / \mathrm{m}^{3}\right)$ & 858.4 & 855.4 & 849.3 & 854.5 & 861.8 & 817.8 \\
\hline Density @ 60 ${ }^{\circ} \mathrm{C}\left(\mathrm{kg} / \mathrm{m}^{3}\right)$ & 851.7 & 848.7 & 842.6 & 847.7 & 855.2 & 810.6 \\
\hline Viscosity @ 40 $\mathrm{C}\left(\mathrm{mm}^{2} / \mathrm{s}\right)$ & 4.43 & 4.36 & 5.45 & 4.48 & 4.79 & 2.95 \\
\hline
\end{tabular}

Were studied: Diesel available in retail and five biodiesel fuels, fatty acid methyl esters of rapeseed oil, marked as Bio1, of rapeseed oil with antioxidant, marked as Bio2, of beef fat, marked as Bio3, of poultry fat, marked as Bio4 and, of used cooking fat, marked as Bio5.The composition of the tested fuels were determined in accordance with PNEN 14103 (Table 1). The density of fuels were determined by the hydrometer in accordance with PN-EN ISO 3675. Kinematic viscosity of studied fuels were determined by capillary according to PN-EN ISO 3104.

\section{Experimental test stand}

The test stand designed for determination of injectors and injection pumps characteristics occurring in the Common Rail system was used to carried out the research. Schema of the test stand shown in Fig. 1. consists of the CR fuel pump (1), which is driven by a toothed belt, by an asynchronous three-phase motor (2) inverter-controlled (19), connected with function control module (5) and drive control module (4). Buttons set (3) is used to turn on the power. Electric fuel pump (16) gives fuel from the tank (14) through the filter (15) to the CR pump. Fuel under high pressure goes, through the distributor (6), to the highpressure rail (7) whence it gets to the injectors (20). The test stand is equipped with fuel dose burette (8), overflow burette (9) and pump efficiency burette (10). Pump tester (12) and injectors tester (13) allow automatic or manual work. Control wires are connected to the terminal block (11). Fuel conditioning is carried out in a system consisting of a heater (21), an electric pump (22) and a radiator (23). The test stand is made in the form of a metal frame on which all necessary supports and devices are attached [15].

Measurements were performed on a Common Rail system electromagnetic injector Bosch with number 044510135 .

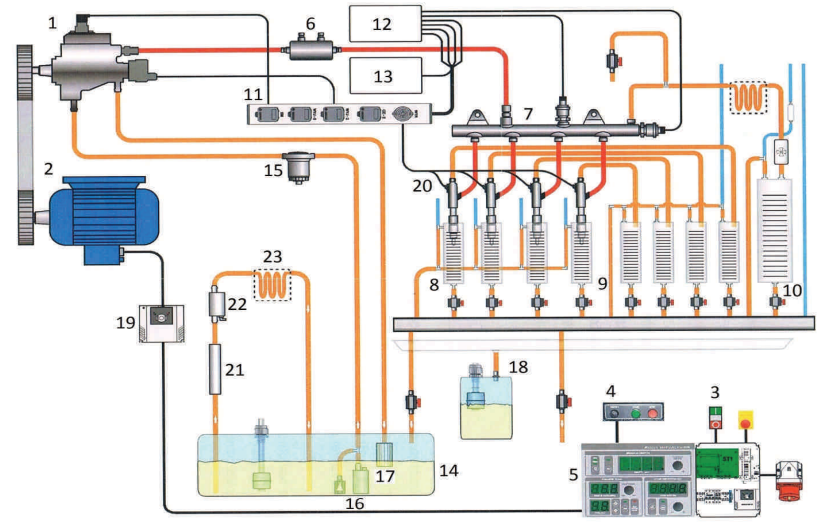

Fig. 1. Schema of test stand used in the experiment [15]

\section{Experimental results and Identification of active flow cross section}

The biofuels used in the research were of different origins, both vegetable and animal. All biofuels were obtained by transesterification using a homogeneous $\mathrm{KOH}$ catalyst. Bio1 and Bio2 fuels were made from rapeseed oil derived directly from the pressing process of raw materials from different sources and in two separate production facilities. The chemical composition is very similar, and the kinematic viscosity value is similar for both fuels (Table 1 and 2). The slight difference in fuel density results from the differences in chemical composition and the antioxidant added.

Other biofuels were made from waste materials. Fuel Bio5 has a similar composition to Bio1 and Bio2 as it is made from rapeseed oil. The differences in composition result from the thermal processes that the oil has undergone and from the biological substances with which the oil was in contact during the treatment. Fuel Bio5 is also characterized by slightly higher viscosity and density, which may have an effect on the fuel injection process.

Fuels Bio3 and Bio4, as opposed to the others, were made from animal waste fats. However, despite differences in origin, Bio4 fuel has a similar viscosity and density to Bio1 and Bio2 fuels. Instead, Bio3 has a lower density and a significantly higher kinematic viscosity at $40^{\circ} \mathrm{C}$. These fuels have a different chemical composition and contain over $20 \%$ of $\mathrm{C} 16$ or lower esters. In addition, a high solidification temperature $\left(14^{\circ} \mathrm{C}\right)$ of the Bio3 fuel was found, which may be significant for its potential use, especially under operating conditions.

Values of individual injections given in $\mathrm{mm}^{3}$ for each inflicted parameters were received as a result of the measurements. Effective injection time, need to determine the volume flow rate as a ratio of the fuel volume injected on the test stand and mentioned effective time, has been calculated based on the values of individual injections as a difference between the time of injector coil supply and time designated by extrapolation of trend line of individual injection on the $\mathrm{x}$ axis. Identified active flow cross section is directly proportional to the volume flow rate of injected fuel and inversely proportional to the square root of the ratio between the value of twice the product of the differential pressure upstream and downstream of the injector and the value of density of the tested fuels. Determined values 
of the active flow cross section were presented in Fig. 2, 3, 4,5 .

At $30^{\circ} \mathrm{C}$ (Fig. 2), the calculated active flow cross section increases to $80 \mathrm{MPa}$, in proportion to the pressure increase for all tested fuels. Afterwards, in the case of diesel, the coefficient is clearly reduced and reached the minimum at pressures of 100 to $140 \mathrm{MPa}$, at higher pressures it rises again to about $3 \mathrm{~mm}^{2}$. For Bio1, Bio2, Bio4 and Bio5 biofuels, which have a similar density and viscosity, the active flow cross section receive a similar value and its course in pressure range from 80 to $180 \mathrm{MPa}$ has a linear function. While the Bio3 active flow cross section obtained maximum $\left(3.1 \mathrm{~mm}^{2}\right)$ at a pressure of $100 \mathrm{MPa}$. With a pressure increase up to $180 \mathrm{MPa}$, the calculated active flow cross section is maintained at a range of 2.75 to 3.1 $\mathrm{mm}^{2}$.The test at this temperature respond to the start-up and warm-up phase of the engine, therefore, in diesel engines, the dose and injection time should be corrected at pressures above $80 \mathrm{MPa}$.

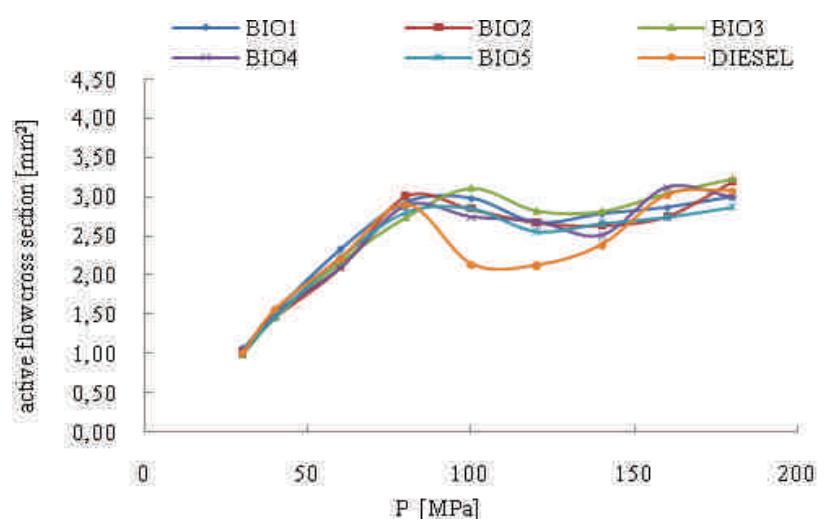

Fig. 2. Comparison of the active flow cross sections of tested fuels at $30^{\circ} \mathrm{C}$

Increasing the fuel temperature to $40^{\circ} \mathrm{C}$ (Fig. 3) changes the course of the active flow cross section. Differences start already above $60 \mathrm{MPa}$. At a pressure of $80 \mathrm{MPa}$ for all tested fuels, apart from Bio3, the active flow cross section achieves the maximum value. The value of the diesel coefficient is almost identical to that of $30^{\circ} \mathrm{C}$. In the case of biofuels, higher active flow cross section values have biofuels produced from rapeseed oil, both raw and processed. However, the highest active flow cross section values for pressures above $60 \mathrm{MPa}$ were found for Bio2 fuel. For other biofuels, the coefficient ranged between 2.4 and 2.7 $\mathrm{mm}^{2}$. Temperature of $40^{\circ} \mathrm{C}$ occurs when the engine is running under normal conditions and at low loads, Therefore, adaptation of the control system of the fuel system should particularly concern a range above $60 \mathrm{MPa}$ to $140 \mathrm{MPa}$.

An increase of the fuel temperature by another $10^{\circ} \mathrm{C}$ (Fig. 4) gives a clear change in the active flow cross section characteristics. In the range of 40 to $60 \mathrm{MPa}$ the active flow cross section for diesel is slightly higher, it stabilizes in the range of 80 to $140 \mathrm{MPa}$ and then increases significantly. For all biofuels, the flow rate increases proportionately to the pressure of $80 \mathrm{MPa}$ and besides the fuel Bio3 reaches its maximum at this pressure. For Bio1 and Bio2 biofuels $\left(1^{\text {st }}\right.$ generation biofuels), the coefficient value is clearly higher at $80 \mathrm{MPa}$. For Bio3 fuel the coefficient reached its highest value at $100 \mathrm{MPa}$. Then, in the pressure range of 100 to 160 $\mathrm{MPa}$, the individual biofuels coefficients reach a similar value and above $120 \mathrm{MPa}$ equate to the diesel factor. The differences reappear for the highest fuel pressure values, and the greatest increase can be seen for Bio2 and diesel fuel.

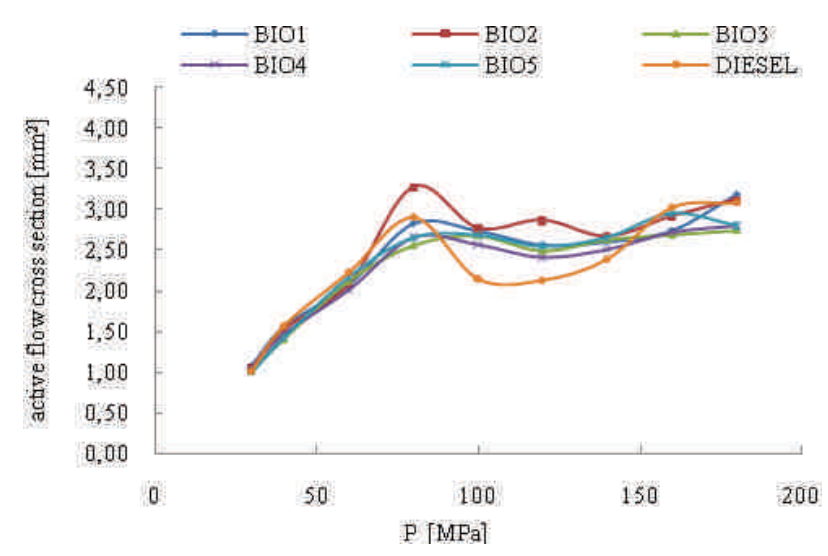

Fig. 3. Comparison of the active flow cross sections of tested fuels at $40^{\circ} \mathrm{C}$

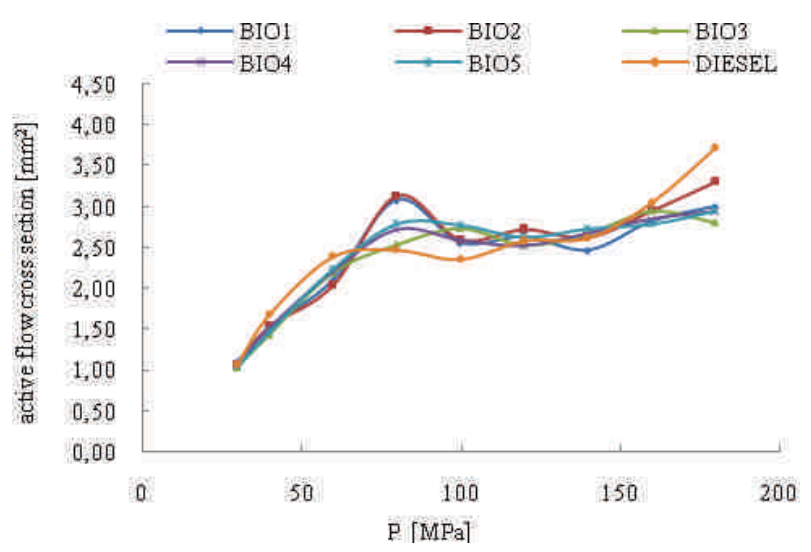

Fig. 4. Comparison of the active flow cross sections of tested fuels at $50^{\circ} \mathrm{C}$

At a temperature of $50^{\circ} \mathrm{C}$, which corresponds to the average engine load, correction of injection parameters should concern fuel doses for pressures from $40 \mathrm{MPa}$ to $120 \mathrm{MPa}$ and above $160 \mathrm{MPa}$ due to the fuel used.

Raising the fuel temperature to $60^{\circ} \mathrm{C}$ (Fig. 5), which corresponds to the maximum thermal load of the engine, deepens the trends observed in the calculated fuel flow characteristics at $50^{\circ} \mathrm{C}$. Again for biofuels proportional increase of the coefficient up to a pressure of $80 \mathrm{MPa}$, then slightly decreases at $100 \mathrm{MPa}$, then $120 \mathrm{MPa}$ starts to grow slowly. For Bio3 biofuel, which has a higher viscosity and lower density, the maximum and minimum local active flow cross sections are offset by $20 \mathrm{MPa}$ towards higher pressures. For diesel, the active flow cross section is clearly increasing at $60 \mathrm{MPa}$, the minimum is at $100 \mathrm{MPa}$, the same as biofuels. A continued increase of pressure results in a proportional increase in the active flow cross section, which, at pressures 160 and $180 \mathrm{MPa}$, is higher than for biofuels. In the case of fuels heated up to $60^{\circ} \mathrm{C}$, the correction in the injection control system includes similar pressure ranges as for a temperature of $50^{\circ} \mathrm{C}$. 


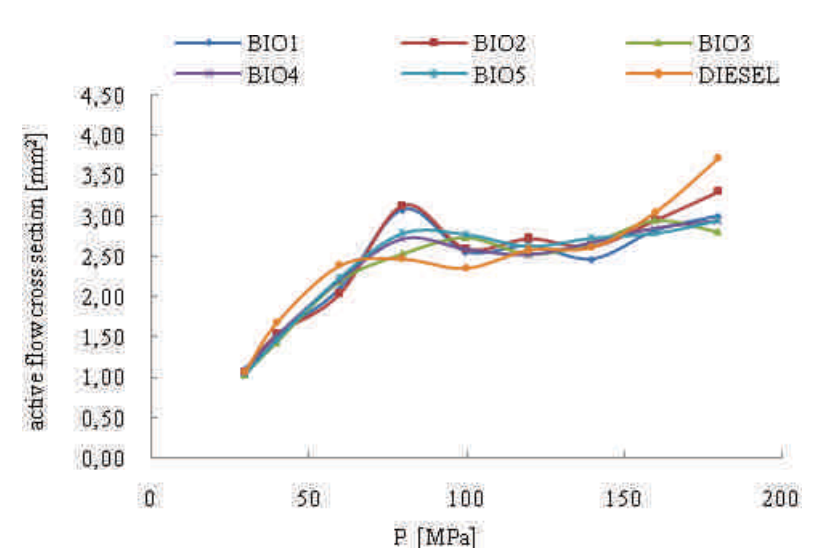

Fig. 5. Comparison of the active flow cross sections of tested fuels at $60^{\circ} \mathrm{C}$

So far, the fuel flow through the injector has been analyzed at the same temperatures. Many authors point to differences in viscosity and density of diesel and biofuels $[6$, $9,10,24]$ indicating that heating of the fuel by 20 or $30^{\circ} \mathrm{C}$ relative to the diesel temperature results in a level of viscosity and density. A similar analysis was done at work Rybak et al. [19]. It has been shown that the active flow cross section for diesel at $40^{\circ} \mathrm{C}$ and for FAME at $60^{\circ} \mathrm{C}$ reach similar values over the range of utility pressures (30 to 180 $\mathrm{MPa}$ ). Therefore, in Figure 6 comparison of the active flow cross sections of tested biofuels at $60^{\circ} \mathrm{C}$ and Diesel at $40^{\circ} \mathrm{C}$ was presented.

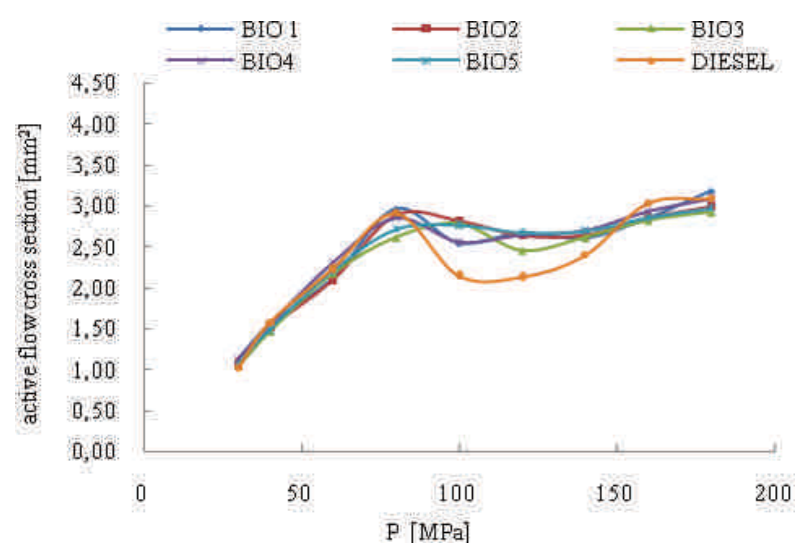

Fig. 6. Comparison of the active flow cross sections of tested biofuels at $60^{\circ} \mathrm{C}$ and Diesel at $40^{\circ} \mathrm{C}$

As a result of this comparison, it can be noted that for both diesel and all biofuels, the active flow cross section increases proportionally between 30 and $80 \mathrm{MPa}$ and beyond the Bio3 fuel, the maximum value is obtained. It can be expected that the fuel dosage in this range will be similar, the difference in engine control will be primarily due to the different chemical composition of each fuel and the thermal conditions of the engine. With a continued increase in pressure (100 to $140 \mathrm{MPa}$ ), there is a difference between

\section{Bibliography}

[1] AGARWAL, A.K, DHAR, A., SRIVASTAVA, D.K., et al. Effect of fuel injection pressure on diesel particulate size and number distribution in a CRDI single cylinder research engine. Fuel. 2013, 107, 84-89. the diesel and biofuel. The difference in fuel dose should be corrected in this interval by any change in the characteristics of the control system and the extension of the diesel injection time or the heating of the fuel by at least $10^{\circ} \mathrm{C}$. The value of the active flow cross section is again equalized for all fuels tested at pressures above $140 \mathrm{MPa}$. The use of such high pressures corresponds to the operation of the engine with maximum loads and under high thermal stress conditions, which in practice is unlikely to keep the diesel temperature at $40^{\circ} \mathrm{C}$. Constant fuel compression and heat transfer by the engine components will cause to heat up the diesel and change the active flow cross section, as can be seen in Figures 4 and 5.

\section{Conclusions}

Comparing the active flow cross section for individual fuels, there was a clear difference in the course of its characteristics as a function of the injection pressure. The coefficient values are also determined by the fuel temperature in common rail system.

At low temperatures $\left(30\right.$ and $\left.40^{\circ} \mathrm{C}\right)$ a proportional increase of coefficient independently to fuel for pressure up to 60-80 MPa can be observed. Then the coefficient for diesel is clearly decreasing $(100-120 \mathrm{MPa})$, at higher pressures again equates to the active flow cross section values for biofuels.

Heating up fuel to 50 or $60^{\circ} \mathrm{C}$ significantly changes the flow rate characteristic, especially for diesel. The differences are already occurring at low pressures, where the biofuel factor is lower. Then the coefficient values are equal in the pressure range from 80 to $140 \mathrm{MPa}$. Above this range again the active flow cross section for diesel rapidly increases.

Conducted comparative analysis of the active flow cross section for different temperatures (Fig. 6) showed that its values for biofuels and diesel are close to in the range up to $80 \mathrm{MPa}$ and above $140 \mathrm{MPa}$. At average pressures, there are still differences between fuels.

In research, fuels of different origins and chemical compositions were used. It can be stated that the active flow cross section for fuel produced from crude rapeseed oil (Bio1 and Bio2) is higher than for fuels from waste materials (Bio3, Bio4 and Bio5). It can be seen that the coefficient for animal derived fuels is lower in comparison with vegetable derived fuels. Significant differences were found for the Bio3 fuel, which had the lowest density among biofuels and the highest viscosity. The maximum flow rate for this fuel was shifted by about $20 \mathrm{MPa}$ towards higher injection pressures, regardless of temperature. In conclusion, it can be stated that the chemical composition of fuels influences the value of the fuel active flow cross section because it determines the physical properties of the fuel (e.g. density, viscosity) and therefore changes the course of the flow rate characteristic as a function of the injection pressure.

[2] BHUIYA, M.M.K., RASUL, M.G., KHAN, M.M.K. et al. Prospects of 2nd generation biodiesel as a sustainable fuelPart 2: Properties, performance and emission characteristics. Renewable and Sustainable Energy Reviews. 2016, 55, 1129-1146. 
[3] BOHL, T., TIAN, G., SMALLBONE, A., ROSKILLY, A.P Macroscopic spray characteristics of next-generation bioderived diesel fuels in comparison to mineral diesel. Applied Energy. 2017, 186, 562-573.

[4] CHOU CH, C., LIN, Y.-W., CHIANG, CH.-J., KU, Y.-Y. Experimental analysis of a turbo-charged common-rail diesel engine fueled with biodiesel. Energy Procedia. 2014, 61, 1167-1170.

[5] DUAN, L., YUAN, S., HU, L. et al. Injection performance and cavitation analysis of an advanced $250 \mathrm{MPa}$ common rail diesel injector. International Journal of Heat and Mass Transfer. 2015, 93, 388-397.

[6] FADHIL, A.B. Evaluation of apricot (Prunus armeniaca L.) seed kernel as a potential feedstock for the production of liquid bio-fuels and activated carbons. Energy Conversion and Management. 2017, 133, 307-317.

[7] FADHIL, A.B., AHMED, A.I., SALIH, H.A. Production of liquid fuels and activated carbons from fish waste. Fuel. 2017, 187, 435-445.

[8] GAVAISES, M., PAPOULIAS, D., ANDRIOTIS, A., GIANNADAKIS, E. Link between cavitation development and erosion damage in diesel injector nozzles. SAE Technical Paper. 2007, 2007-01-0246.

[9] GOLIMOWSKI, W., BERGER, W.A., PASYNIUK, P. et al. Biofuel parameter dependence on waste fats' fatty acids profile. Fuel. 2017, 197, 482-487.

[10] GÜLÜM, M., BILGIN, A. Measurements and empirical correlations in predicting biodiesel-diesel blends' viscosity and density. Fuel. 2017, 199, 567-577.

[11] HWANG, J., QI, D., JUNG, Y., BAE, CH. Effect of injection parameters on the combustion and emission characteristics in a common-rail direct injection diesel engine fueled with waste cooking oil biodiesel. Renewable Energy. 2014, 63, 9-17.

[12] KALARGARIS, I., TIAN, G., GU, S. Influence of advanced injection timing and fuel additive on combustion, performance, and emission characteristics of a DI diesel engine running on plastic pyrolysis oil. Journal of Combustion. 2017, 3126342, 9 .

[13] KUTI, O. A., ZHU, J., NISHIDA, K. et al. Characterization of spray and combustion processes of biodiesel fuel injected by diesel engine common rail system. Fuel. 2013, 104, 838846.

[14] MO, J., TANG, C., LI, J. et al. Experimental investigation on the effect of n-butanol blending on spray characteristics of soybean biodiesel in a common-rail fuel injection system. Fuel. 2016, 182, 391-401.

[15] Opis techniczny stanowiska testowania pomp i wtryskiwaczy STPiW3. Centrum Szkolenia Motoryzacji "Autoelektronika Kędzia". Nr kat.: 1120. 2015.

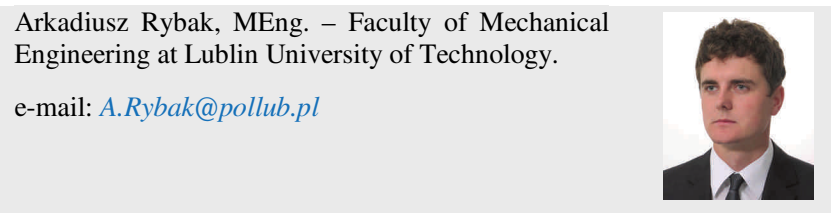

Paweł Krzaczek, DEng. - Faculty of Production Engineering at University of Life Sciences.

e-mail:Pawel.Krzaczek@up.lublin.pl
[16] OSIPOWICZ, T., STOECK, T., GOEEBIEWSKI, W. Influence of fuel pollutants on operating parameters of contemporary fuel injector. Journal of KONES Powertrain and Transport. 2015, 22(3), 169-174.

[17] PAYRI, R., SALVADOR, F. J., MARTÍ-ALDARAVÍ, P., MARTIINEZ-LÓPEZ, J. Using one-dimensional modeling to analyse the influence of the use of biodiesels on the dynamic behavior of solenoid-operated injectors in common rail systems: Detailed injection system model. Energy Conversion and Management. 2012, 54, 90-99.

[18] QIU, T., SONG, X., LEI, Y. et al. Effect of back pressure on nozzle inner flow in fuel injector. Fuel. 2016, 173, 79-89.

[19] RYBAK, A., GECA, M., KRZACZEK, P., MAZANEK, A. Determination of common rail injector flow characteristics with the use of diesel and biodiesel fuels. Journal of KONES. 2016, 23(4), 443-450.

[20] SALVADOR, F.J., DE LA MORENA J., MARTÍNEZLÓPEZ, J., JARAMILLO, D. Assessment of compressibility effects on internal nozzle flow in diesel injectors at very high injection pressures. Energy Conversion and Management. 2017, 132, 221-230.

[21] SINGH, P.V., CHAUHAN, S.R. Carbonyl and aromatic hydrocarbon emissions from diesel engine exhaust using different feedstock: a review. Renewable and Sustainable Energy Reviews. 2016, 63, 269-291.

[22] SLAVINSKAS, S., MICKEVICIUS, T. Experimental study on injection characteristics of diesel-bioethanol fuel blends. Combustion Engines. 2015, 161(2), 28-32.

[23] SOMA, S., LONGMAN, D.E., RAMÍREZ A.I., AGGARWAL, S.K., A comparison of injector flow and spray characteristics of biodiesel with petrodiesel. Fuel. 2010, 89, 4014-4024.

[24] TAKASE, M., ZHAO, T., ZHANG, M. et al. An expatiate review of neem, jatropha, rubber and karanja as multipurpose non-edible biodiesel resources and comparison of their fuel, engine and emission properties. Renewable and Sustainable Energy Reviews. 2015, 43, 495-520.

[25] WASILEWSKI, J., KRZACZEK, P. Emission of toxic compounds from combustion of biodiesel: a report from studies. Przemyst Chemiczny. 2014, 93(3), 343-346.

[26] XANG, X., HUANG, Z., ZHANG, W.B, et al. Effects of ultra-high injection pressure and micro-hole nozzle on flame structure and soot formation of impinging diesel spray. Applied Energy. 2011, 88, 1620-1628.

[27] YALIWAL, V.S., BANAPURMATH, N.R., GIREESH, N.M. et al. Effect of nozzle and combustion chamber geometry on the performance of a diesel engine operated on dual fuel mode using renewable fuels. Renewable Energy. 2016, 93, 483-501.

Damian Marcinkowski, DEng. - Institute of Technology and Life Sciences in Poznań.

e-mail: D.Marcinkowski@itp.edu.pl

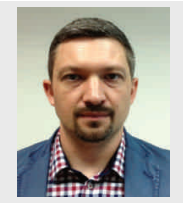

